\title{
The use of the nonlinear models in the growth of pears of 'Shinseiki' cultivar
}

\author{
Thais Destefani Ribeiro $^{1^{*}}$ Taciana Villela Savian ${ }^{2}$ \\ Tales Jesus Fernandes ${ }^{3}$ Joel Augusto Muniz ${ }^{3}$
} 1Programa de Pós-Graduação em Estatística e Experimentação Agropecuária, Departamento de Estatística (DES), Universidade Federal de
Lavras (UFLA), 37200-000, Lavras, MG, Brasil. E-mail: t.destefani.ribeiro@gmail.com. *Corresponding author.
${ }^{2}$ Departamento de Ciências Exatas, Escola Superior de Agricultura Luiz de Queiroz (ESALQ), Universidade de São Paulo (USP), Piracicaba, SP, Brasil.
${ }^{3}$ Departamento de Estatística (DES), Universidade Federal de Lavras (UFLA), Lavras, MG, Brasil.

ABSTRACT: The goal of this study was to elucidate the growth and development of the Asian pear fruit, on the grounds of length, diameter and fresh weight determined over time, using the non-linear Gompertz and Logistic models. The specifications of the models were assessed utilizing the $R$ statistical software, via the least squares method and iterative Gauss-Newton process (DRAPER \& SMITH, 2014). The residual standard deviation, adjusted coefficient of determination and the Akaike information criterion were used to compare the models. The residual correlations, observed in the data for length and diameter, were modeled using the second-order regression process to render the residuals independent. The logistic model was highly suitable in demonstrating the data, revealing the Asian pear fruit growth to be sigmoid in shape, showing remarkable development for three variables. It showed an average of up to 125 days for length and diameter and 140 days for fresh fruit weight, with values of $72 \mathrm{~mm}$ length, $80 \mathrm{~mm}$ diameter and $224 \mathrm{~g}$ heavy fat.

Key words: Biometric measurements, Asian pear, model Gompertz, logistic model.

\author{
O uso de modelos não lineares na descrição do \\ crescimento de frutos de pereira cultivar 'Shinseiki'
}

RESUMO: Este trabalho teve por objetivo descrever o crescimento e desenvolvimento de frutos de pereira asiática, com base no comprimento, diâmetro e peso fresco obtidos ao longo do tempo, pelos modelos não lineares Gompertz e Logístico. Os parâmetros dos modelos foram estimados utilizando rotinas no software $R$, pelo método de mínimos quadrados e processo iterativo de Gauss-Newton (DRAPER \& SMITH, 2014). Os modelos foram comparados utilizando o desvio padrão residual, coeficiente de determinação ajustado e o critério de informação de Akaike. A correlação residual presente nos dados de comprimento e diâmetro foi modelada por processo auto-regressivo de segunda ordem, tornando os resíduos independentes. O modelo Logístico mostrou-se mais adequado para descrever os dados, comprovando o caráter sigmoidal do crescimento da pera asiática com desenvolvimento acentuado das três variáveis, com até 125 dias para o comprimento e diâmetro e 140 dias para o peso fresco dos frutos, estabilizando-se, em média, com $72 \mathrm{~mm}$ de comprimento, $80 \mathrm{~mm}$ de diâmetro e $224 \mathrm{~g}$ de peso fresco. Palavras-chave: medidas biométricas, pera asiática, modelo Gompertz, modelo Logístico.

\section{INTRODUCTION}

A member of the family Rosacea, the pear, genus Pyrus, includes more than 20 species. In Brazil, the most important are Peraeuropeia, Pyruscommunis L., oriental pear, Asian or Japanese pear, Pyruspyrifolia (Burm) Nak., and the hybrid variety arising from a cross between the two types last mentioned (NAKASU et al., 2007). The leading oriental pear cultivars grown in Brazil include the Nijisseiki, Kosui, Hosui, Suisei and Shinseiki varieties (ARRUDA \& CAMELLATO, 1999).
China is the global leader in pear production, generating 17 million tonnes of fruit, with the United States, Argentina, Italy and Spain following in ranking (FAOSTAT, 2016). In Brazil; however, the pear has still not reached outstanding status among the fruit of greater expression, although it remains the third most consumed fruit of the temperate zone (FIORAVANÇO \& ANTONIOLLI, 2016). Based on the reports of FIORAVANÇO \& OLIVEIRA (2014), 90\% of the pears consumed in Brazil are imported, chiefly from Argentina, 
with Portugal, Spain and the United States being the other suppliers. In Brazil, pear production amounts to a mere $10 \%$ of the consumption and its cultivation is restricted largely to the Rio Grande do Sul (48.1\%), as well as Santa Catarina (18.9\%), and Paraná (11.1\%) with the remaining from São Paulo and Minas Gerais.

In terms of relevance that the pear tree bears to Brazil, FIORAVANÇO \& ANTONIOLLI (2016) reported that this is the chief fruit grown under temperate climatic conditions that is yet to be fully exploited. This observation was made from the data on pear consumption in Brazil. The fact that the pears consumed are almost wholly imported is a clear indicator for the necessity for further research that would provide sufficient information to attract the producers. Cultivating the pear tree in southern Brazil showed great potential, as the technological and storage infrastructure utilized in the cultivation of apple trees can be easily implemented for it (LOPES et al., 2011). In Brazil, notable among the factors that prevent pear tree cultivation are the deficiency of suitable rootstocks (PASA, 2012), and the less effective fructification, which influences the crop indices (HAWERROTH et al., 2011). During the harvest, pears must necessarily meet size and quality standards before they can be marketed to the consumer for the longest period of time; only then they can compete with the imported pears. Therefore, it is essential that the technologies employed guarantee improvement in all aspects of quality, throughout the production chain (ANTONIOLLI et al., 2012).

Investigating the fruit growth patterns facilitates the establishment of appropriate harvesting procedures, handling techniques, post harvest conservation, as well as maturation and quality indices (ARAÚJO NETO et al., 2011). The harvest point has been frequently identified as one of the chief post-harvest loss factors. In most instances, it is assessed subjectively from the visible fruit color and size, as no consensual standardization has been set up by the producers (CAVALINI et al., 2006). Therefore, the employment of growth models in describing fruit development using standard estimation of the parameters enables the identification of the suitable harvesting point for each marketing location.

The pear harvest point is ascertained depending on the physical, chemical and physiological methods or combinations of all three (NAKASU et al., 2007). The authors propose that the physical dimensions of fruit length and diameter enable determination of the harvesting point, taking into account that some of the pear cultivars are capable of completing their maturation under refrigeration, during storage in chambers. According to FIORAVANÇO \& ANTONIOLLI (2016), in the case of the Asian pears, as the fruits are harvested ripe and are fit for immediate consumption, pulp firmness is a significant harvesting point indicator. European pears; conversely, have the capacity to complete the ripening process post harvest. Number of days that lapse between the date of full bloom and harvest point was used as the indicator of the maturation index of the hybrid pear (BETTIOL NETO et al., 2014). The authors reported a mean value of 138 days and fruit length and diameter were estimated, as well as the post-harvest variables including color, firmness, titratable acidity, and soluble solids, besides others.

In studies concerning the development of various species, several nonlinear models have proven to be more suitable than the linear ones in describing plant growth as they include better adjustments and provide estimates of the parameters with biological interpretation (SOUSA et al., 2014). The Gompertz and Logistic growth models were effective in describing the cacao fruit development (MUNIZ et al., 2017), and the fruits of the cashew tree (MUIANGA et al., 2016), dopequi (FERNANDES et al., 2015), and coffee tree (FERNANDES et al., 2014), giving satisfactory results, for all instances. JESUS et al., (2008) in their study of the longan fruit growth, did a comparison of the Logistic and Quadratic Exponential models and observed that the Logistic model fitted better. According to BRUNETTO et al., (2015) the Mitscherlich nonlinear model was adequate in estimating the relative yield of pear trees in three production cycles, enabling the assessment of the response of the plant to the application of phosphate and potassium fertilizers.

The parameters assessed in the non-linear models, from the classical perspective, are commonly dependent on the minimization of the sum of the squares of residues, which is the system followed by the normal nonlinear equations which lack explicit solutions, and require the use of the iterative methods. The commonest among the iterative procedures is the non-linear regression Gauss-Newton algorithm (DRAPER \& SMITH, 2014; SAVIAN \& MUNIZ, 2007). The aim of this work was to evaluate the possibility of utilizing the nonlinear regression models to describe the growth and identification of the harvest point, based on the visible physical characteristics viz., length $(\mathrm{mm})$, diameter $(\mathrm{mm})$ and fresh weight $(\mathrm{g})$ of the Shinseiki pear variety. 


\section{MATERIALS AND METHODS}

An experiment performed in a commercial orchard in the city of Canguçu, RS provided the data used to fit the models (LOMBARDI et al., 2000). The authors had considered the research in two stages in which the fruit development was determined every 14 days until the fruit reached 134 days in age post anthesis, based on the average data, for each assessment. Between November 1997 and February 1998, 11 observations were made in total, per variable studied. The length $(\mathrm{mm})$, diameter $(\mathrm{mm})$ and fresh weight $(\mathrm{g})$ were recorded, besides the other variables depending on the fruit sample at each age.

The parameters of the growth curve in pears were estimated using the nonlinear Gompertz (1) and Logistic models (2), based on the equations given: $y_{i}=A e^{-e(B-k t)}+u_{i}$ (1) e $y_{i}=A /\left(1+e_{i}^{(B-k t)}\right)+u_{i}$ (2), respectively, where $u_{i}=\varnothing u_{i-1}+\ldots+\varnothing_{p} u_{i-p}+\varepsilon_{i}$, with $\mathrm{i}=1,2, \ldots, \mathrm{n}$ and $\mathrm{n}$ refers to the number of times the growth measurements were taken; $u_{i}$ is the residue of the adjustment in the $\mathrm{i}$-th time; $\varnothing_{1}$ is the autoregressive parameter of the order $1 ; u_{i-1}$ is the residue of the time adjustment immediately preceding the $i$-th measurement; $\varnothing_{p}$ the autoregressive parameter of order $\mathrm{p} ; u_{i-p}$ is the residue of the time-period adjustment prior to the i-th measurement; $\varepsilon_{i}$ is the white residue, with normal distribution $N\left(0, \sigma^{2}\right)$.

When the residuals are independent, the parameters $\varnothing_{i}$ are null, and consequently $u_{i}-\varepsilon_{i}$ (MUIANGA et al., 2016). CASSIANO \& SÁFADI (2015) reiterated that time-ordered sets of data are normally autocorrelated, which must be taken into account and modeled to ensure more highly accurate estimates and better quality in the adjustment of the models.

In equations (1) and (2), $y_{i}$ indicates the mean value of the length $(\mathrm{mm})$, diameter $(\mathrm{mm})$ and fresh weight $(\mathrm{g})$ of the pear fruit in time $t_{i}$, in days; A refers to the asymptotic value of the assessments, meaning, the value of the variables at the time of the full development of the pear; $\mathrm{B}$ is the location parameter, with no biological interpretation; $\mathrm{k}$ shows the growth rate of the pear for fresh weight in $\mathrm{g} \mathrm{day}^{-1}$, and mm day ${ }^{-1}$ for length and diameter; $t_{i}$ refers to the $\mathrm{i}$-th measurement time, expressed in days after full bloom, where $\mathrm{i}=1,2, \ldots, 11$. For the adjustment of the models considering the autoregressive error structure as well as the tests for the (PINHEIRO et al., 2016), "car" (FOX \& WEISBERG, 2011), "qpcr" (SPIESS, 2014) and "l test" were used to obtain quality assessors. (ZEILEIS \& HOTHORN, 2002) of software R (R DEVELOPMENT CORE TEAM, 2016).
To confirm the homogeneity of e variances and normality of the residuals, the Breusch and Pagan and Shapiro-Wilk tests were applied. To assess the residual autocorrelation, the ARp structure was considered, and with $\mathrm{p}=1,2,3,4$, the Durbin-Watson test was considered to account for the lags; when the test was significant, the particular parameter was incorporated into the model. Models were compared with due consideration given to the agronomic interpretation of the parameter estimates, as well as to the quality of the adjustment, based on the following criteria: i) Residual Standard Deviation (RSD), calculated by the expression $\mathrm{RSD}=\sqrt{\mathrm{RMS}}$, with $\mathrm{RMS}$ representing the residual mean square (DRAPER and SMITH, 2014); (ii) Adjusted coefficient of determination $\left(\mathrm{R}^{2}{ }_{\mathrm{aj}}\right)$, calculated by: $\mathrm{R}^{2}{ }_{\mathrm{aj}}=1-\left(\left(1-\mathrm{R}^{2}\right)(\mathrm{n}-1) /(\mathrm{n}-\mathrm{p})\right)$ with $\mathrm{R}^{2}$ indicating the unadjusted coefficient of determination, $\mathrm{n}$ the number of times measurements were performed and $p$ the total number of parameters included in the model; iii) Akaike information criterion is given by: $\operatorname{AIC}=-2 \log \mathrm{L}(\tilde{\theta})+2 \mathrm{p}$, where $\tilde{\theta}$ is the maximum likelihood estimator, is the maximum of the likelihood function, $p$ the number of parameters in the model and $\log$ the natural logarithmic operator (AKAIKE, 1974).

For the models adjusted, the 95\% confidence intervals for the parameters $\hat{\theta}_{i}$ based on the expression IC $\left(\hat{\theta}_{i}\right)=\hat{\theta}_{i} \pm t_{(u, 0,025)} S\left(\hat{\theta}_{i}\right)$ were determined, where the $\hat{\theta}_{i}$ was the estimate of the parameter $\theta_{i}$ of the model; $t_{(u, 0,025)}$ the value of Student's t distribution with $v=n-p$ degrees of freedom and area 0.025 on its right; $S\left(\hat{\theta}_{i}\right)$ is the standard error of the $\theta_{i}$, parameter estimate,given by the square root of the respective term of the diagonal of the asymptotic matrix of variances and covariates. The findings of the confidence interval were represented by the lower limit (LL) and upper limit (UL).

\section{RESULTS AND DISCUSSION}

From the current study the inferences drawn demonstrated the usefulness of applying the non-linear regression models to growth studies with Asian pear fruits, according to the data reported by LOMBARDI et al. (2000). Values for the given estimates are valid for the climatic conditions of Canguçu, RS, during the data collection period. In terms of the standardized residue analyses for the Gompertz and Logistic models to be adjusted to the data on the Asian pear fruit length, diameter and fresh weight for the Shapiro-Wilk (SW) and BreuschPagan (BP) tests, the assumptions of normality and homogeneity of variances for the vector of residues required in the analyses were seen to be met in all the 
variables and models; hence, the residual estimates remained unchanged, with constant variance and normal distribution.

From the Durbin-Watson test (DW), the presence of residual autocorrelation was evident for fruit length in the Logistic model and for diameter in the Gompertz model, necessitating the incorporation of the second-order autoregressive process parameters. Similar findings were reported by PRADO et al., (2013); MUNIZ et al., (2017); MUIANGA et al., (2016) and SOUSA et al. (2014). They recorded autocorrelated errors in the adjustment of the nonlinear regression models to the growth data of the green dwarf coconut, cacao and cashew fruits and coffee seed germination, respectively.

Table 1 lists the estimates of the parameters and respective confidence intervals of $95 \%$ probability, based on the adjustments of the Gompertz and Logistic models, for the values of length $(\mathrm{mm})$, diameter $(\mathrm{mm})$ and fresh weight $(\mathrm{g})$; the quality of adjustment for the same models and characteristics are shown in table 2. Confidence Intervals (CI) presented in table 1, generally revealed small amplitude, indicating accurate estimates with low margin of error and soon higher levels of adjustment of the models. It can still be claimed that the parameters were different from zero, as this value was not included in the estimated CI.

In terms of fruit length (Table 2), the values of the coefficient of determination $\left(\mathrm{R}_{\mathrm{aj}}^{2}\right)$ were above 0.98 , implying satisfactory adjustments. For the evaluators, residual standard deviation (DPR) and Akaike's information criterion (AIC), the logistic model revealed lower values, suggesting a better fit; also, according to the findings of FERNANDES et al., (2015) the lower AIC values suggested that this model best describes the data. Therefore, the adjustment quality evaluators highlight the superiority of the Logistic model with second order autoregressive errors to describe the pear fruit length increase.

As indicated in table 2, for the diameter, the Gompertz model showed dependent residue and the incorporation of the second order autoregressive parameter caused the residue to be independent. Similar findings were reported by MUNIZ et al. (2017), MUIANGA et al. (2016) and CASSIANO \& SÁFADI (2015) in their studies on growth, in which the residual dependence was modeled by autoregressive order $\mathrm{AR}_{\mathrm{p}}$. In the current study, the logistic model offered the best results corroborating the findings of PRADO et al., (2013), who also reported a better fit by this model in their studies on the green dwarf cocus fruit diameter.

The higher performance of the Logistic model in describing the data was noteworthy, as it showed greater parsimony because, as evident from tables 1 and 2, its adjustment presented fewer parameters. When the variable fresh weight was considered (Table 2), the Logistic model demonstrated the lowest DPR and AIC values, indicating a better adjustment of the data, as in the cases of the variables of length and diameter.

Based on the estimates by the models of parameter (A) displayed in table 1, it is evident that the final fruit length of the pear was $72 \mathrm{~mm}$ on average

Table 1 - Estimates of the parameters and respective confidence intervals (CI) of 95\% probability, based on thea djustments of the Gompertz and Logistic models, for values of length $(\mathrm{mm})$, diameter $(\mathrm{mm})$ and fresh weight $(\mathrm{g})$ of Asian pear fruits.

\begin{tabular}{|c|c|c|c|c|c|}
\hline \multirow[t]{2}{*}{ Characteristics } & \multirow[t]{2}{*}{ Models } & \multicolumn{4}{|c|}{ 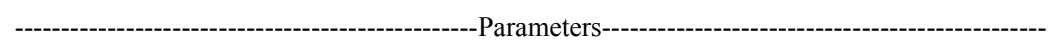 } \\
\hline & & A & B & $\mathrm{k}$ & $\emptyset_{2}$ \\
\hline & Logistic & 72.17 & 53.30 & 0.039 & -0.29 \\
\hline \multirow[t]{4}{*}{ Lenght (mm) } & $\mathrm{CI}$ & {$[70.8 ; 73.6]$} & {$[51.0 ; 54.8]$} & {$[0.03 ; 0.04]$} & {$[-0.4 ;-0.2]$} \\
\hline & Gompertz & 76.01 & 39.94 & 0.026 & - \\
\hline & $\mathrm{CI}$ & {$[71.9 ; 80.1]$} & {$[36.6 ; 43.3]$} & {$[0.02 ; 0.03]$} & - \\
\hline & Logistic & 79.59 & 54.99 & 0.049 & - \\
\hline \multirow[t]{4}{*}{ Diameter (mm) } & $\mathrm{CI}$ & [79.2;79.9] & {$[54.7 ; 55.4]$} & {$[0.04 ; 0.06]$} & - \\
\hline & Gompertz & 83.41 & 42.58 & 0.031 & -0.87 \\
\hline & $\mathrm{CI}$ & {$[79.6 ; 86.3]$} & {$[41.4 ; 45.5]$} & {$[0.03 ; 0.04]$} & {$[-1.3 ;-0.5]$} \\
\hline & Logistic & 224.42 & 103.46 & 0.0762 & - \\
\hline \multirow[t]{3}{*}{ FreshWeight (g) } & $\mathrm{CI}$ & {$[211 ; 237]$} & {$[100 ; 106]$} & {$[0.06 ; 0.09]$} & - \\
\hline & Gompertz & 237.79 & 96.69 & 0.0479 & - \\
\hline & CI & {$[212 ; 263]$} & {$[92 ; 100]$} & {$[0.03 ; 0.06]$} & - \\
\hline
\end{tabular}


Table 2 - Quality of adjustment for the Gompertz and Logistic models, for the values of length $(\mathrm{mm})$, diameter $(\mathrm{mm})$ and fresh weight $(\mathrm{g})$ of Asian pear fruits.

\begin{tabular}{lcccc}
\hline Characteristics & Models & \multicolumn{4}{c}{------Adjustment-------- } \\
\hline \multirow{2}{*}{ Lenght $(\mathrm{mm})$} & Logistic & 0.99 & 0.82 & 11.97 \\
& Gompertz & 0.99 & 1.78 & 17.11 \\
\hline Diameter $(\mathrm{mm})$ & Logistic & 0.99 & 0.51 & 7.35 \\
& Gompertz & 0.83 & 1.43 & 13.35 \\
\hline FreshWeight $(\mathrm{g})$ & Logistic & 0.98 & 13.24 & 32.72 \\
& Gompertz & 0.97 & 16.81 & 34.58 \\
\hline
\end{tabular}

for the Logistic model, with a growth rate of $0.039 \mathrm{~mm}$ day $^{-1}$. This finding concurs with the reports of LOMBARDI et al., (2000) and HAWERROTH et al. (2011), as they recorded a value of around $72 \mathrm{~mm}$ soon after the Asian pear fruits were harvested. However, the Gompertz model overestimated the final fruit length of the Asian pear, showing values closer to the ones reported for the European pear fruits, according to PARRA-CORONADO et al. (2006).

For diameter, the values of parameter (A) estimated, as shown in table 1, indicate that the pear fruit had an average diameter of $83.4 \mathrm{~mm}$ for the Gompertz model and $79.5 \mathrm{~mm}$ for the Logistic model. Therefore, the value estimated by the latter model showed greater similarity to the values reported by LOMBARDI et al., (2000) who recorded an average of $81 \mathrm{~mm}$ just after the Asian pear fruits were harvested. It is interesting to note that the CI for the estimation the value obtained by the author. Besides describing the data adequately, the Logistic model gave values that were quite consistent with the literature (LOMBARDI et al., 2000; HAWERROTH et al., 2011). An average growth rate of $0.049 \mathrm{~mm}^{\text {day }}{ }^{-1}$ was observed, and the value was expected to be greater than the length because of the measurements of the final fruit.

Based on the estimates of the parameters of fresh weight by the Logistic model (Table 1), the final fresh weight was found to be on average $224 \mathrm{~g}$, concurring with the findings of LOMBARDI et al., (2000) for pear fruits. Mean growth rate for the weight of $0.0763 \mathrm{~g} \mathrm{day}^{-1}$ was also consistent. Figure 1 shows the graphs of the adjustment of the Gompertz and Logistic models to the growth data of the Asian pear fruits for the variables of length $(\mathrm{mm})$, diameter $(\mathrm{mm})$ and fresh weight $(\mathrm{g})$. All the variables visibly reveal the sigmoidal shape during fruit development, in agreement with the reports of FIORAVANÇO \& ANTONIOLLI (2016) on the growth curve character of the Asian pear fruit.

As evident; although, both the models to give a good fit to the three variables studied in the fruits, the Logistic model came closest to the data, and showed the best fit. The graph makes it clear that the fruit length and diameter showed the fastest growth rate until around 125 days, after which the development slowed down until the $154^{\text {th }}$ day after anthesis, when harvesting was done. The fruit length and diameter increased to around $80 \%$ of the total, until 125 days after the anthesis. This finding confirmed the observations of FIORAVANÇO \& ANTONIOLLI (2016) on the Asian pear growth stages, thus establishing the conclusion of the experiment, second stage, when growth stabilization occurs after this age of 125 days.

For the variable fresh weight of the fruits $(\mathrm{g})$, an initial slow growth rate seen until 70 days, after which the development accelerates, and
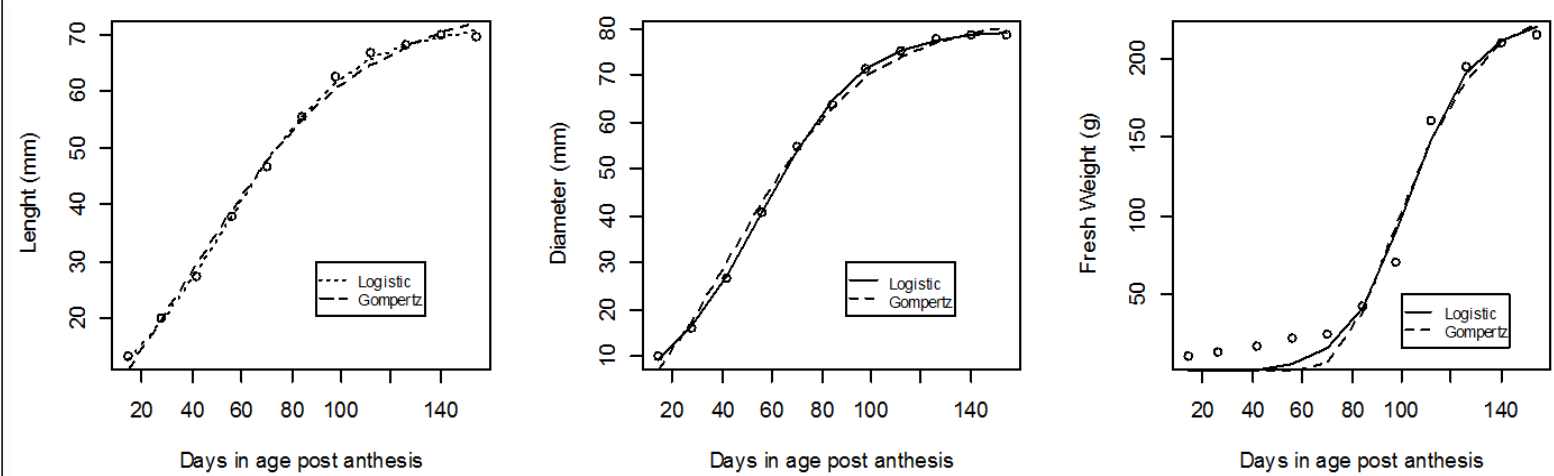

Figure 1 - Graphs of thea djustment of the Gompertz and Logistic models to the growth data of the Asian pear fruits for the variables of length $(\mathrm{mm})$, diameter $(\mathrm{mm})$ and fresh weight $(\mathrm{g})$. 
finally stabilizes the weight of the pear fruits after 140 days. According to LOMBARDI et al. (2000), the Asian pear fruit revealed a slower initial growth rate, although after around 60 days there was an accelerated sigmoidal growth in terms of the length, diameter and fresh weight, until it stabilized. It was then harvested at day 154 after anthesis.

Finally, even with a good fit to the data for fresh weight, it was noteworthy that both models underestimated the initial fruit weights; however, after around 70 days post anthesis they overlapped the values observed, indicating that the Logistic model was even closer to these values and more adequately revealed the growth of the Asian pear fruits. The adjustment of the Gompertz and Logistic sigmoid models to the Asian pear growth data confirmed the potential that these models have for practical use by researchers and producers, and their ability to provide pertinent data for pear tree management.

\section{CONCLUSION}

In light of the environmental conditions under which the data collection was done, the Asian pear fruit development is best described by the nonlinear regression models, and particularly by the Logistic model, considering the autoregressive error of the second order for length $(\mathrm{mm})$. The model adequately described fruit growth in length $(\mathrm{mm})$, diameter $(\mathrm{mm})$ and fresh weight $(\mathrm{g})$ showing a sigmoidal character; the length and diameter stabilization occurred 125 days after anthesis; whereas, for fresh weight it took place at 140 days. With growth rates of $0.039 \mathrm{~mm} \mathrm{dia}^{-1}$; $0.049 \mathrm{~mm}$ day $^{-1} \mathrm{e}$ and $0.076 \mathrm{~g} \mathrm{day}^{-1}$ the final dimensions at the time of harvest was on average $72 \mathrm{~mm}, 80 \mathrm{~mm}$ and $224 \mathrm{~g}$, respectively, for fruit length, diameter and fresh weight.

\section{ACKNOWLEDGEMENTS}

The authors are grateful to Conselho Nacional de Desenvolvimento Científico e Tecnológico (CNPq) and Coordenação de Aperfeiçoamento de Pessoal de Nível Superior (CAPES) for all the support in this research.

\section{REFERENCES}

AKAIKE, H. A. New Look at the Statistical Model Identification. IEEE Transsctionson Automatic Control, Minato-ku, v.19, n.6, p.716-723, 1974. Available from: <http://dx.doi.org/10.1007/978-1-4612-16940_16>. Accessed: nov, 17, 2017. doi: 10.1007/978-1-4612-1694-0_16.

ANTONIOLLI, L. R et al. Metodologia para evidenciar danos mecânicos gerados por atrito em peras. Bento Gonçalves, RS: Embrapa Comunicado Técnico 127, 2012. p. 1-8.
ARAÚJO NETO et al. Desenvolvimento de frutos de sapotizeiros. Revista Brasileira de Fruticultura. Jaboticabal, v. 23, n. 1, p. 25-29, 2001. Avaiable from: <http://www.bdpa.cnptia.embrapa.br/consulta/bu $\mathrm{sca} ? \mathrm{~b}=\mathrm{ad} \& \mathrm{id}=636091 \&$ biblioteca $=\mathrm{CNPMF} \&$ busca $=$ autoria:\%22ARA $\%$ C3\%9AJO $\% 20$ NETO, $\% 20$ S. $\% 20$ E. $\% 20 \mathrm{de} \% 22 \&$ qFacets=autoria: $\%$ 22ARA\%C3\%9AJO \%20NETO,\%20S.\%20E.\%20de\%22\&sort=\&pag inacao $=t \&$ paginaAtual $=1>$. Accessed: nov, 17, 2017. ISSN 0100-2945.

ARRUDA, J. J. P.; CAMELLATO, D. abortamento de gemas florais de cinco cultivares de pereira (Pyrusapp,L) em dois locais do Rio Grande do Sul, Brasil. Ciência Rural, v.29, n.4, p.635-638, 1999. Available from: <https://doi.org/10.1590\%2Fs0103-84781999000400011>. Accessed: nov, 17, 2017. doi: 10.1590/s0103-84781999000400011.

BETTIOL NETO J. E. et al. Produção e qualidade pós-colheita de cultivares de pereira nas condições subtropicais da Região Leste Paulista. Ciência Rural, Santa Maria, v.44, n. 10, p. 1740-1746, 2014. Available from: <https://doi.org/10.1590\%2F0103-8478cr20131574>. Accessed: nov, 17, 2017. doi: 10.1590/0103-8478cr20131574.

BRUNETTO, G. et al. The pear tree response to phosphorus and potassium fertilization. Revista Brasileira de Fruticultura, Jaboticabal, v.37,n.2, p.507-516, 2015. Available from: $<$ https://doi.org/10.1590\%2F0100-2945-027\%2F14>. Accessed: nov, 17, 2017. doi: 10.1590/0100-2945-027/14.

CASSIANO, F. R. SÁFADI, T. Modelos de crescimento animal para tempos irregulares. Pesq. Agop. Bras. Brasília, v. 50, n. 11, p. 11141119. Nov 2015. Available from: <https://doi.org/10.1590\%2Fs0100204x2015001100015>. Accessed: nov, 17, 2017. doi: 10.1590/s0100$204 \times 2015001100015$.

CAVALINI F. C. et al. Maturity indexes for 'Kumagai' and 'Paluma' guavas. Revista Brasileira de Fruticultura, Jaboticabal, v. 28, p. 176-179, 2006. Avaiable from: <http://dx.doi.org/10.1590/S010029452006000200005>. Accessed: nov, 17, 2017. doi: 10.1590/010029452006000200005.

DRAPER, N. R., SMITH, H. Applied regression analysis. $3^{\text {rd }}$ ed., reprint. New York: John Wiley, 2014, 736p.

FAOSTAT. Cropsand Trade: Cropsanslivestokproducts. Available from: <http://faostat3.fao.org/browse/T/TP/E > . Accessed: jul, 11, 2016.

FERNANDES, T. J., et al. Parameterization effects in nonlinear models to describe growth curves. Acta Scentiarum Technology, Maringá, v.37, n. 4, p. 397-402, Oct.-Dec., 2015. Available from: $<$ https://doi.org/10.4025\%2Factascitechnol.v37i4.27855>. Accessed: nov, 17, 2017. doi: 10.4025\%2Factascitechnol.v37i4.27855.

FERNANDES, T. J., et al. Seleção de modelos não lineares para a descrição das curvas de crescimento do fruto do cafeeiro. CofSci, Lavras, v. 9, n. 2, p. 207-215, abr./jun. 2014. Avaiable from: <http:// www.coffeescience.ufla.br/index.php/Coffeescience/article/ view/618>. Accessed: nov, 17, 2017. doi: 10.25186/cs.v9i2.618.

FIORAVANÇO, J. C.; ANTONIOLLI, L. R. Pera: O produtor pergunta, a Embrapa responde. Embrapa Uva e Vinho - Coleção Criar, Plantar. Brasília, DF, 229p, 2016.

FIORAVANÇO, J. C.; OLIVEIRA, P. R. de. Produção e importação Brasileira de pera no período 2001 a 2012. Informações econômicas, v. 44, n. 6, p. 16-22, 2014. Available from: <https:// ainfo.cnptia.embrapa.br/digital/bitstream/item/129112/1/fioravancoinformacoeseconomicas-v44-n6-nov-dez-2014-p16-22.pdf>. Accessed: nov, 17, 2017. ID: $15995-2$. 
FOX, J.; WEISBERG, S. An $\{\mathbf{R}\}$ Companion toApplied Regression. $2^{\mathrm{a}}$ ed. Thousand Oaks CA: Sage, 2011. Disponível em: $<\mathrm{http}: / /$ socserv. socsci.mcmaster.ca/jfox/Books/Companion>. Accessed: 13/062017.

HAWERROTH, F. J. et al. Fruit production increase in Asian pear trees by use of plant growth regulators. Ciência Rural, Santa Maria, v. 41, n. 10 , p. $1750-1754,2011$. Available from: <https://doi. org/10.1590\%2Fs0103-84782011001000012>. Accessed: nov, 17, 2017. doi: 10.1590/s0103-84782011001000012.

JESUS, N. de et al. Desenvolvimento de frutos de longan (Dimo carpus longan Lour) na região de Jaboticabal, SP. Revista Brasileira de Fruticultura, v.30, n.1, p.159-164, 2008. Available from: <https://doi.org/10.1590\%2Fs0100-29452008000100029>. Accessed: nov, 17, 2017. doi: 10.1590\%2Fs0100-29452008000100029.

LOMBARDI, S. R. B. et al. Avaliação do crescimento pós-colheita de peras da cultivar shinsseike. Pesquisa Agropecuária Brasileira, Brasília, v. 35 , n. 12 , p. 2399-2405, 2000. Available from: <https://doi.org/10.1590\%2Fs0100-204x2000001200010>. Accessed: nov, 17, 2017. doi: 10.1590/s0100-204x2000001200010.

LOPES T. P. et al. Comparação dos princípios tecnológicos do processamento do suco de maçã aos de pera. Revista Brasileira de Tecnologia Industrial, Ponta Grossa, v. 5, n. 2, p. 593-905, 2011. Available from: <https://doi.org/10.3895\%2Fs1981-36862011000200011> Accessed: nov, 17, 2017. doi: 10.3895/s1981-36862011000200011.

MUIANGA, C.A. et al. Descrição da curva de crescimento de frutos do cajueiro por modelos não lineares. Revista Brasileira de Fruticultura, Jaboticabal, v. 38, n. 1, p. 022-032, 2016. Available from: $<$ https://doi.org/10.1590\%2F0100-2945-295\%2F14>. Accessed: nov, 17, 2017. doi: 10.1590/0100-2945-295/14.

MUNIZ, J.A. et al. Nonlinear models for description of cacao fruit growth with assumption violations. Revista Caatinga, Mossoró, v. 30, n. 1, p. 250-257, 2017. Available from: <https://doi.org/10.1590\%2F1983-21252017v30n128rc >. Accessed: nov, 17, 2017. doi: 10.1590/1983-21252017v30n128rc.

NAKASU B. H. et al. A cultura de pera. Embrapa Informação Tecnológica, Brasília, 58p. 2007.

PARRA-CORONADO, A. et al. Estudio de algunas propiedades físicas y fisiológicas precosecha de La pera variedad triunfo de Viena.
Rev. Bras. Frut., Jaboticabal, v. 28, n. 1, p.55-59, 2006. Available from: < https://doi.org/10.1590\%2Fs0100-29452006000100017>. Accessed: nov, 17, 2017. doi: 10.1590/s0100-29452006000100017.

PASA, M. da S. T. et al. Desenvolvimento, produtividade e qualidade de peras sobre porta-enxertos de marmeleiro e Pyrus calleryana. Rev. Bras. de Frut., Jaboticabal, v. 34, n. 3, p. 873-880, 2012. Available from: <https://doi.org/10.1590\%2Fs0100-29452012000300029>. Accessed: nov, 17, 2017. doi: 10.1590/s0100-29452012000300029.

PINHEIRO J. et al. R CORE TEAM nIme: Linear and Nonlinear Mixed Effects Models (R Core Team). R package version 3.1-128, 2016. Avaiable from: <http://CRAN.R-project.org/ package $=$ nlme $>$. Accessed: jun, 13,2017.

PRADO et al. Ajuste dos modelo Logístico na descrição do crescimento de frutos de coqueiro anão por meio de algoritmos iterativos MCMC. Rev. Bras. Biom., São Paulo, v.31, n.2, p.216-232, 2013. Available from: <https://doi.org/10.1590\%2 Fs0103-84782013005000044>. Accessed: nov, 17, 2017. doi: 10.1590/s0103-84782013005000044.

R DEVELOPMENT CORE TEAM. R: a languagean denvironment for statistical computing. Vienna: R Foundation for Statistical Computing, 2012.

SAVIAN T. V.; MUNIZ, J. A. A Study of in situ degradability: Heterogeneity of variances and correlated errors. Scientia Agrícola, Piracicaba, v. 64, p. 548-554, 2007. Available from: <https://doi.org/10. 1590\%2Fs0103-90162007000500013>. Accessed: nov, 17, 2017. doi: 10.1590/s0103-90162007000500013.

SOUSA, I. F.et al. Fitting nonlinear autoregressive models to describe coffee seed germination. Ciência Rural, Santa Maria, v.44, n. 11, p. 2016-2021, nov. 2014. Available from: <https://doi.org/10.1590\%2F0103-8478cr20131341>. Accessed: nov, 17, 2017. doi: $10.1590 / 0103-8478 \mathrm{cr} 20131341$.

SPIESS, A-N. qpcR: Modelling and analysis of real-time PCR data. R packageversion 1.4-0, 2014. Available from: <https:/CRAN.Rproject.org/package $=q p c R>$. Accessed: jun, 13, 2017.

ZEILEIS, A.; HOTHORN, T. Diagnostic Checking in Regression Relationships. R News 2(3), 7-10, 2002. Available from: <http:// CRAN.R-project.org/doc/Rnews/>. Accessed: jun, 13, 2017. 